Central European Journal of Energetic Materials, 2016, 13(1), 3-19

ISSN 1733-7178

e-ISSN 2353-1843

\title{
Environmental Long Term Impact on a Romanian Military Testing Range
}

\author{
Răzvan PETRE ${ }^{1}$, Traian ROTARIU ${ }^{2 *}$, Teodora ZECHERU ${ }^{1}$, \\ Nicoleta PETREA ${ }^{1}$, Sorina BĂJENARU ${ }^{1}$ \\ ${ }^{1}$ Scientific Research Center for CBRN Defense and Ecology, \\ 225 Şos. Oltenitei, 041309 Bucharest, Romania \\ ${ }^{2}$ Military Technical Academy, 39-49 Bd. George Coşbuc, \\ 050141 Bucharest, Romania \\ *E-mail: traian.rotariu@gmail.com
}

\begin{abstract}
Military range management has become extremely important in recent years, in order to comply with the limitations imposed by national and international environmental regulations. In this regard, soil, vegetation and ground water samples from a testing facility belonging to the Romanian Ministry of National Defense were analyzed for contamination with metals and energetic materials. The tests confirmed the presence of contaminants as energetic materials and heavy metals $(\mathrm{Pb}, \mathrm{Cu}, \mathrm{Zn})$, with a heterogeneous distribution on the range and concentrated in the impact and firing line areas.
\end{abstract}

Keywords: contamination, analytical methods, heavy metals, energetic materials

\section{Introduction}

The use of armament systems and munitions during instruction or testing/ evaluation for armed forces' readiness is mandatory. The presence of energetic materials (EMs) and metals cannot be avoided, implying there is a permanent risk of air, soil and water pollution with compounds resulting from EM combustion. EMs exhibit a particular risk to the environment due to their hazardous physicochemical and toxicological properties. Consequently, many countries have become aware of the necessity of implementing measures that ensure the 
lowest environmental risk during national defence activities, which implies their examination and selection in order to limit as far as possible the environmental risks. The growing need for amenable environmental policy development has become obvious, especially in the last decade, when a large number of military bases have been closed and armament systems demilitarized.

In this context, a large number of military ranges have been targeted for investigation and/or clean-up in recent years under various environmental regulations [1-3]. A number of studies [4-6] have evaluated the environmental impact of contaminants from the firing of bombs, rockets, projectiles, and pyrotechnics, on the quality of soil, ground water and surface water. Depending on the depth of the ground water, climate, soil parameters, or the proximity of surface water on the range, contaminants can reach ground or surface waters. Left unmanaged, contaminants from a range may lead to important health hazards to wildlife and people who are exposed to the affected environment $[1-3,6]$.

Although contamination at military bases is often localized in one or a few areas, a particular problem in the evaluation of the nature and the extent of contamination at military facilities is that the exact areas of impact are sometimes not completely delineated. Consequently, environmental agencies frequently conclude that the contaminated site is, in fact, the entire active area of the base $[7,8]$.

When firing of conventional munitions, beside the typical gaseous combustion products, heavy metals are also dispersed in the firing area. This can be due either to the combustion of EMs used for casting, or the erosion of the metallic components of the cartridge, projectile or tube. Moreover, in the impact area, degradation products of EMs and residues from the projectiles (primers, high explosives, boosters, and pyrotechnics) are found, as well as metallic parts resulting from fragmentation. Heavy metals are found worldwide in a broad range of environments, the type of soil and climate being the main factors influencing their absorption into plants and penetration into the water. $\mathrm{Pb}$ is the main contaminant of shooting ranges, and researchers worldwide have described range contamination (soil, water, and vegetation) and various modes of decontamination have been proposed. In addition to $\mathrm{Pb}$, other contaminants such as $\mathrm{Sb}, \mathrm{Cu}, \mathrm{Zn}, \mathrm{Ni}$ and $\mathrm{As}$, were analyzed, taking into account the fact that they may be of equal or greater concern for ecotoxicity.

Special concern has also been given lately to EMs. During firing, the propellant is burnt and gases are formed. In the case of munitions firing, it has been shown [9] that over $99.99 \%$ of the EM is turned into gases (without including here the pyrotechnics). Unexploded ordnance (UXO) and incomplete detonation rates are very low $(<5 \%)$. On the majority of ranges, $\mathrm{UXO}$ clearance operations 
after firing are mandatory. As a consequence, a certain amount of solid product is formed. The burning of these products may affect the environment by spreading hazardous substances in the atmosphere.

During the last few years, an increased number of issues have arisen in Romania in relation to hazardous contaminants, UXOs, and military range clean-up. Thus, the present case study aimed to assess in-depth the degree of contamination of the soil, vegetation and aquifers with munition residues on an experimental military range of the Romanian Ministry of National Defense (MoND), both in terms of heavy metals and EMs. Regarding the in-depth soil tests on military ranges, to our knowledge this kind of field study has never been published previously.

\section{Materials and Methods}

\subsection{Study region and statistical data}

The experimental range studied is situated in the south-eastern part of Romania

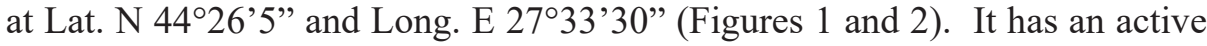
area of $\sim 14 \mathrm{~km}^{2}$ (14 km in length and $1 \mathrm{~km}$ wide). Its surface is perfectly flat, with a uniform altitude of $38 \mathrm{~m}$, allowing very good visibility of the munitions during their entire flight. The soil structure is typical for a Danube meadow. The tectonic foundation is situated at over $1,300 \mathrm{~m}$ depth. On top of that, there is a thick blanket of sediments produced during several sedimentation cycles between the Cambrian and Neocene periods. From a lithological point of view, these deposits consist of clay, sandy-clay, loess and fine sand.

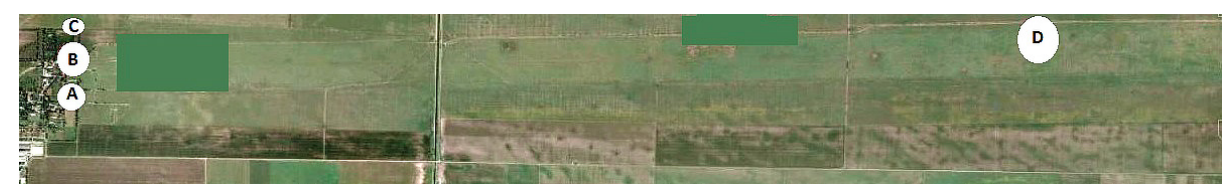

Figure 1. Sampling areas: A - small arms area, B - artillery weapons area, $\mathrm{C}$ - pyrotechnics area, D - impact area.

The climate is continental temperate, with continental accents, excessive tones and high temperature amplitudes between the summer and winter seasons. Winter polar winds from the east cause the temperature to drop below $-25^{\circ} \mathrm{C}$ in winter. During summer, the highest recorded temperatures in this Romanian region are frequently over $40{ }^{\circ} \mathrm{C}$. The number of tropical days in this region is also the highest in Romania (40 to 60 days/year). 


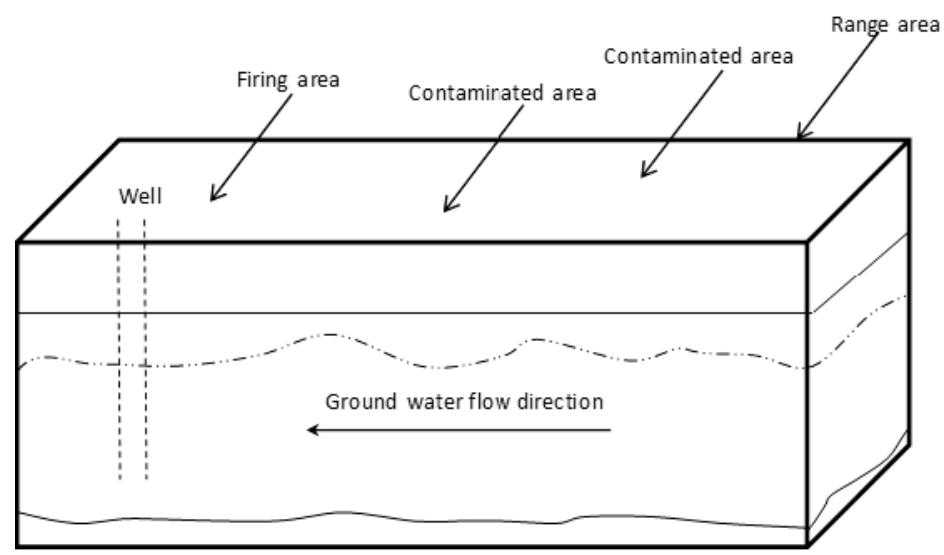

Figure 2. Ground water flow direction.

The average precipitation is very low ( 400 to $500 \mathrm{~mm} /$ year), causing long dry periods (80 to 100 days) at the beginning and the end of the vegetation period. The hydrographical network of the South Baragan Plane has a very low density $\left(<17 \mathrm{~km} / \mathrm{km}^{2}\right)$. Thus, the area of the range is essentially clear of surface water, excluding some irrigation channels that are no longer in use, after 1990.

Because of the dry climate, the first aquifer is situated at depths of 20 to $25 \mathrm{~m}$, at the intersection between the loessoid deposits and fine sands. The water in this aquifer has an average $\mathrm{pH}$ of 7.5 and $20^{\circ} \mathrm{G}$ hardness.

The range is used mainly for ground tests of artillery and mortar systems, grenades, hand grenades, rockets, small arms, fuses and pyrotechnics, for periodical tests and also for $\mathrm{R} \& \mathrm{D}$, etc. Therefore, the exploitation extent of the range can be considered rather high. Because of the lack of long-term statistics of the firing management, the available data on the fired munitions was only for the past 15 years. During this period, the following were identified as having been used: small arms munitions in the range $5.45 \mathrm{~mm}$ to $14.5 \mathrm{~mm}$ cal.; mortars 82 to $122 \mathrm{~mm}$ cal.; rocket grenades (PG 7, PG 9); cannon and howitzer projectiles 25 to $152 \mathrm{~mm}$ cal.; antitank and antipersonnel grenades; smoke grenades and smoke candles.

The data on the specific number of munitions fired is classified, but statistics on the hazardous materials (explosives and metals) from the munitions and energetic materials fired on the range within the last 15 years amounts to $40,000 \mathrm{~kg}$ TNT, $6,000 \mathrm{~kg}$ RDX and 335,000 kg metals. The UXOs are neutralized at the site where found, or in a subsurface detonation area situated at $5 \mathrm{~km}$ from the firing line. The sampling has been performed after having received accurate data on the firing and the affected areas. 


\subsection{Sampling and risk analysis methodology}

\subsubsection{Sampling strategy}

Taking into account the specific situation of the range, a multi-increment sampling strategy for artillery ranges was employed, in agreement with other studies [10].

After having consulted the range firing management, the sampling targeted the firing area, the impact area, the intermediary area, and the neutralization (detonation) area.

The methods used for soil and vegetation sample collection from different areas of the range were (Figure 3): multi-increment sampling in large square areas, usually $100 \mathrm{~m}^{2}(10 \times 10 \mathrm{~m})$; multi-increment sampling along a circle at different distances from hot spots; composite sampling from hot spot areas ( 30 subsamples per $1 \mathrm{~m}^{2}$ ); core sampling to a maximum depth of $3 \mathrm{~m}$ in hot spot areas.
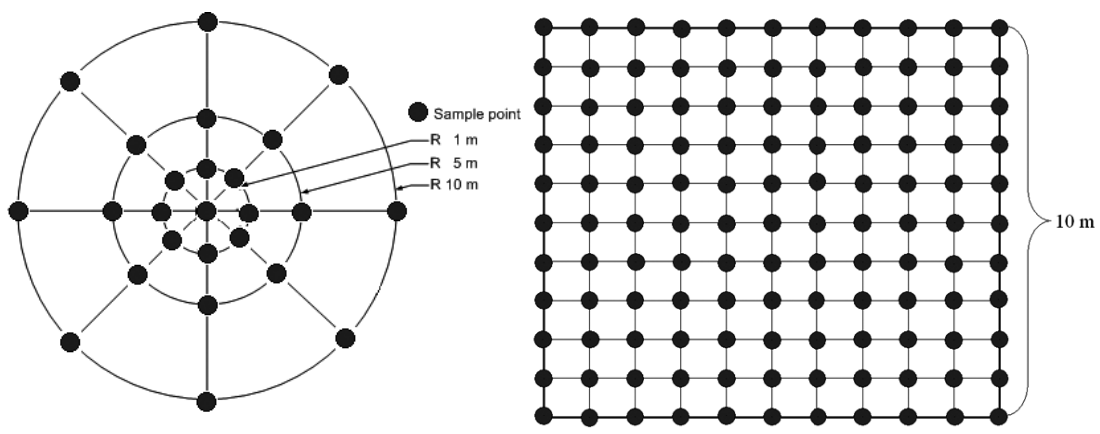

Figure 3. Multi-increment sampling points.

All of the samples were collected in plastic bags, labelled, recorded with the GPS coordinates and stored at $4{ }^{\circ} \mathrm{C}$ until sample preparation. Subsamples for the chemical analysis of explosives were taken and weighed immediately after grinding and stored in a freezer. Surface subsamples of $\sim 10 \mathrm{~g}$ were taken using steel scoops, usually from 2.5 to $5 \mathrm{~cm}$ in depth. $1 \mathrm{~kg}$ composite samples were placed in polyethylene sealed bags and stored in the freezer until sample preparation. Core samples were collected only from hot spot areas, using a specialized assay tool kit AMS Inc. (USA). This tool kit allowed sampling of $1 \mathrm{~kg}$ cylindrical samples at depths varying from 20 to $300 \mathrm{~cm}$.

Due to the depth of the first aquifer, it was not possible to create new wells for water sampling. Thus, it was decided to use the existing well situated in the area near the firing line of the range. This decision was also supported by the ground water flow direction, towards the Danube (Figure 2). Water samples were taken in triplicate from here, during one year at three monthly intervals. 


\subsubsection{Methods}

\section{Heavy metals in soil samples}

In order to determine the heavy metal content in the soil samples (elemental and ions), an Atomic Absorption Spectrometer (AAS) Perkin Elmer Analyst 800 was used. The analytical procedure was performed in line with the national standards $[11,12]$ as follows: the soil samples were first dried, milled and sieved. Afterwards, a representative $0.5 \mathrm{~g}$ subsample was digested with a homogenous $3: 1$ (v:v) mixture of nitric and hydrochloric acids (20:1, v:w, versus the subsample). Digestion of the samples was performed in a Berghof MW-2 apparatus, using a three-step temperature program: $25 \mathrm{~min}$ at $180{ }^{\circ} \mathrm{C}, 10 \mathrm{~min}$ at $100{ }^{\circ} \mathrm{C}$ and $10 \min$ at $40{ }^{\circ} \mathrm{C}$.

Traditional flame atomic absorption has a relatively poor sensitivity for $\mathrm{Hg}$. Therefore, $\mathrm{Hg}$ has been determined by reduction to metallic $\mathrm{Hg}$ using $\mathrm{NaBH}_{4}$ and then analyzed by the cold vapor technique. This method is based on the fact that, under normal conditions of temperature and pressure, the ground state of the $\mathrm{Hg}$ atoms produced have a high vapor pressure and subsequently are transported by argon and measured, without flame atomization. After digestion, the sample was reduced with a $1 \%(\mathrm{~m}: \mathrm{v}) \mathrm{NaBH}_{4}$ solution in alkaline medium. The gaseous reaction mixture, consisting of $\mathrm{Hg}$ in excess $\mathrm{H}_{2}$, was transported to the quartz cell by an Ar flow.

The threshold concentrations stipulated by the national legislation (legal background level-LBGL) regarding soil quality, were considered as a reference for this study. Due to the fact that a military range was being evaluated, the values obtained were compared with the thresholds for less sensitive soils.

In order to determine the background concentration level (BGL), two blank composite surface soil samples from uncontaminated soil were taken from the administrative area (which is at approx. $1 \mathrm{~km}$ away from the main firing area) of the range as a reference. Furthermore, composite, hot spot and core samples were also taken and analyzed from the small arms firing position. Other composite and hot spot soil samples were collected from an area where smoke grenades and smoke candles are frequently fired, from the firing position for artillery systems (mortars, canons and howitzers) and from the UXO disposal site (Figure 1). Composite samples, collected from a $1 \mathrm{~m}^{2}$ area in the impact area and composed of 30 subsamples weighing $1 \mathrm{~kg}$, were also analyzed.

\section{Heavy metals in vegetation samples}

Vegetation samples (herbs) from the small arms firing line area, from the pyrotechnic munitions (smoke grenades and smoke candles) firing area, and 
from the UXO disposal area were analyzed. The metal content of the vegetation samples was also determined by AAS. $0.25 \mathrm{~g}$ of representative subsamples were collected from composite samples and digested with a mixture of nitric acid and hydrogen peroxide $(2: 3, \mathrm{v}: \mathrm{v})$. A three-step temperature program for the Berghof MW-2 digestor was employed: $5 \mathrm{~min}$ at $145^{\circ} \mathrm{C}, 10 \mathrm{~min}$ at $180{ }^{\circ} \mathrm{C}$ and $10 \mathrm{~min}$ at $100{ }^{\circ} \mathrm{C}$.

\section{Anions, cations and heavy metals in the aquifer}

In order to determine the extent of contamination of the aquifer with heavy metals, EMs and other pollutants, water samples were obtained from a 25 m-depth of the well situated in the south-eastern part of the range. The water samples were taken every three months, over one year.

Elemental heavy metals and their cations from various compounds were determined by VIS spectrometry using a Hach-Lange DR 2800 spectrophotometer.

\section{EMs from soil and water samples}

A preliminary qualitative measurement was performed using a REX KIT 08 colorimetric kit for EMs produced by STIMPEX SA. This colorimetric kit is based on Meisenheimer and Griess complexes and gives a qualitative assessment of samples regarding the presence of nitro-derivatives in ppm concentrations. A positive response led to quantitative evaluation by HPLC or GC-MS.

Furthermore, for all of the soil samples collected, the EPA 8330 HPLC method presented in [13] was employed. A high pressure liquid chromatograph Thermo Electron Corporation Surveyor Plus was used, equipped with photodiode array detector (Surveyor PDA Plus) and a quaternary pump. The LC was fitted with a Hypersil Gold C18, $5 \mu \mathrm{m}$ column, the oven temperature was held at $30{ }^{\circ} \mathrm{C}$, the detection was made at $254 \mathrm{~nm}$ wavelength and the mobile phase consisted of a 60:40 water:methanol mixture at a flow rate of $0.8 \mathrm{~mL} \cdot \mathrm{min}^{-1}$. The detection limit was determined using soil samples spiked with five explosives and nitro-derivatives at known concentrations [2,4,6-trinitrotoluene (TNT), 2,4-dinitrotoluene (DNT), hexahydro-1,3,5-trinitro-1,3,5-triazine (RDX), 1,3-dinitrobenzene (DNB), and nitrobenzene (NB)] [14]. The detection limit for these analytes was found to be between 3.2 and $115 \mu \mathrm{g} \cdot \mathrm{kg}^{-1}$. 


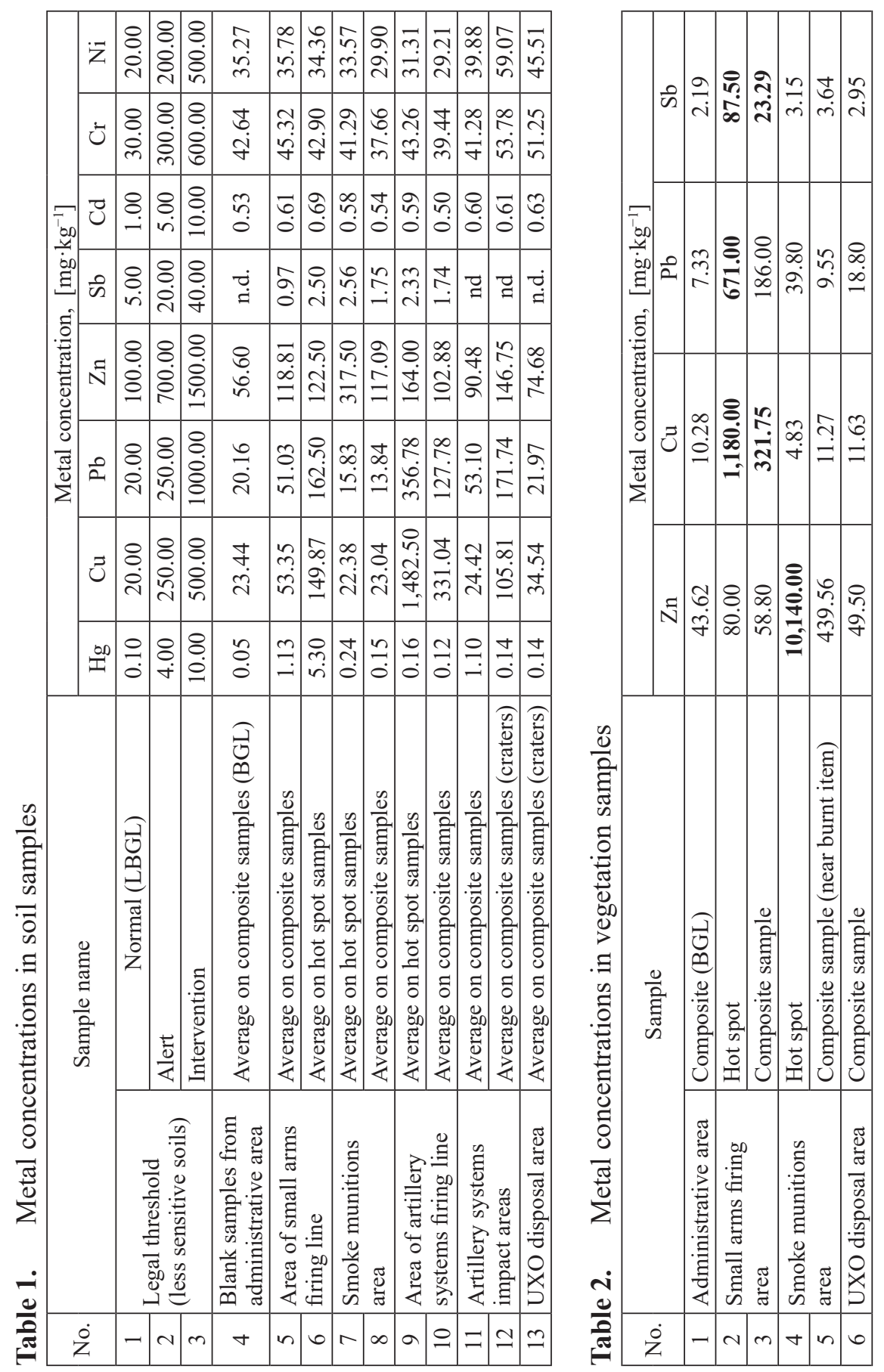




\section{Results and Discussion}

\subsection{Soil sample evaluation}

Table 1 lists the results from the analysis of the metal concentrations in the soil samples versus LBGL (row 1), the alert threshold (row 2), the intervention threshold (row 3) and the BGL (row 4).

High concentrations of heavy metals were found at the infantry munitions firing area. Regarding the area of the firing line for small arms, the main contaminants were also the main components of the infantry ammunitions: $\mathrm{Hg}$, $\mathrm{Cu}, \mathrm{Pb}, \mathrm{Zn}$, and, in lower amounts, $\mathrm{Sb}$. The averaged results for the composite samples indicated a slight contamination of this area, but the values obtained are far below the alert limits, and closer to the normal and reference values. Higher concentrations were found for these contaminants versus BGL and LBGL, but still below the alert threshold. The concentrations in hot spots were considerably higher, but still below the alert value for $\mathrm{Cu}\left(149.87 \mathrm{mg} \cdot \mathrm{kg}^{-1}\right), \mathrm{Pb}$ $\left(162.50 \mathrm{mg} \cdot \mathrm{kg}^{-1}\right)$ and $\mathrm{Zn}\left(122.50 \mathrm{mg} \cdot \mathrm{kg}^{-1}\right)$, except for $\mathrm{Hg}\left(5.30 \mathrm{mg} \cdot \mathrm{kg}^{-1}\right)$ which was above the $4 \mathrm{mg} \cdot \mathrm{kg}^{-1}$ alert concentration. The source of $\mathrm{Hg}$ contamination consists in the use of ammunition equipped with percussion caps belonging to the first generation of primers, comprising priming mixtures based on mercury fulminate and potassium chlorate. This type of primer can now be found only in very old stocks of ammunition that are no longer produced in Europe, so this should not be a major concern for the range management, but should constitute an issue for the monitoring activity and a soil remediation programme.

The sources of $\mathrm{Cu}, \mathrm{Pb}$ and $\mathrm{Zn}$ contamination can be identified in the inherent composition of the EMs and the metallic parts of conventional rounds. The reduction of $\mathrm{Pb}$ compounds and $\mathrm{Pb}$ itself in small arms ammunition is an important issue on the MoD's agenda [15-17] and efforts were made by several producers to replace $\mathrm{Pb}$ with $\mathrm{Cu}$ and $\mathrm{W}$ composites. However $\mathrm{Cu}$ and $\mathrm{W}$ contamination problems were encountered due to the advanced erosion of composite bullets.

The results obtained from composite and hot spot soil samples collected from the pyrotechnic munitions area are also given in Table 1. The measurements made in the pyrotechnics area revealed important concentrations of $\mathrm{Zn}$ $\left(317.50 \mathrm{mg} \cdot \mathrm{kg}^{-1}\right)$, localized in the hot spots where pyrotechnic items were burnt, but they were still below the alert limit for less sensitive soils. The averaged concentration in the composite samples $\left(117.09 \mathrm{mg} \cdot \mathrm{kg}^{-1}\right)$ from this area was close to the normal and to the reference values.

The results of the AAS analysis of composite and hot spot soil samples taken from the firing position for artillery systems did not indicate major concentrations 
of $\mathrm{Hg}$, but important concentrations of $\mathrm{Pb}$ above the alert threshold were found in the hot spots $\left(356.78 \mathrm{mg} \cdot \mathrm{kg}^{-1}\right)$, but below this threshold for the composite sample $\left(127.78 \mathrm{mg} \cdot \mathrm{kg}^{-1}\right)$, and $\mathrm{Cu}$ concentrations above the intervention limit were found in certain hot spots $\left(1,482.50 \mathrm{mg} \cdot \mathrm{kg}^{-1}\right)$ and even in composite samples (331.04 $\left.\mathrm{mg} \cdot \mathrm{kg}^{-1}\right)$. Contamination with these metals is due to the presence of combustion products from primers and propellants $(\mathrm{Pb})$, but also to projectile erosion $(\mathrm{Cu})$. Careful monitoring of the contamination level in this area is recommended, so that specific remediation measures can be applied when the intervention limits are exceeded.

Composite and hot-spot samples from the impact areas were also analyzed. The collections were made in the areas with the maximum probability of munitions functioning, as indicated by the range management, to be at $1,000 \pm 0.1 \%, 1,300 \pm 0.1 \%, 1,500 \pm 0.1 \%, 5,000 \pm 0.1 \%$ and $7,000 \pm 0.1 \% \mathrm{~m}$ from the firing line. Two types of composite samples were analyzed: composites obtained from random square areas and composites from circular shapes around the impact craters. The heavy metals concentrations in the composite samples were slightly above the BGLs and LBGLs, especially in the cases of $\mathrm{Cu}, \mathrm{Zn}, \mathrm{Cr}$, and $\mathrm{Ni}$, but way below the alert threshold. In the hot spot and composite samples from the crater areas, the $\mathrm{Cu}$ (maximum $224.97 \mathrm{mg} \cdot \mathrm{kg}^{-1}$ ) and $\mathrm{Pb}$ (maximum $187.00 \mathrm{mg} \cdot \mathrm{kg}^{-1}$ ) concentrations were just below the alert thresholds, the other metals being in concentrations close to those of the composite samples. The results obtained from samples collected from the UXO disposal areas showed metal concentrations very close to those corresponding to BGL and LBGL.

An important finding of the present work, which has not been studied previously, were the results from the experiments regarding the depth variation of metal concentrations. Core samples from ground level to $2 \mathrm{~m}$ deep were collected for the most contaminated sites (small arms firing area, artillery firing area and pyrotechnics area) and analyzed for the presence of three relevant metals: $\mathrm{Cu}, \mathrm{Pb}$ and $\mathrm{Zn}$. The results are presented in Figure 4 and reveal a very rapid decrease in the concentrations with depth. The illustration of the rapid decrease in the concentrations has proved that from practically $0.5 \mathrm{~m}$ depth, the metal concentrations revert to values close to BGL and LBGL. This finding is very important for the assessment of the fate of these metallic contaminants in the specific environment of the range, because it practically excludes the possibility of ground water contamination, the first aquifer being situated at a minimum of $20 \mathrm{~m}$ depth. 


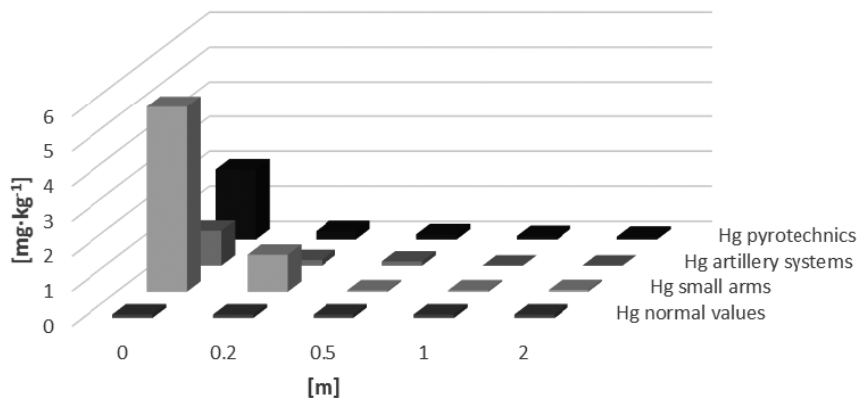

a Hg normal values $\quad \mathrm{Hg}$ small arms $\quad \mathrm{Hg}$ artillery systems $\mathbf{m} \mathrm{Hg}$ pyrotechnics

a)

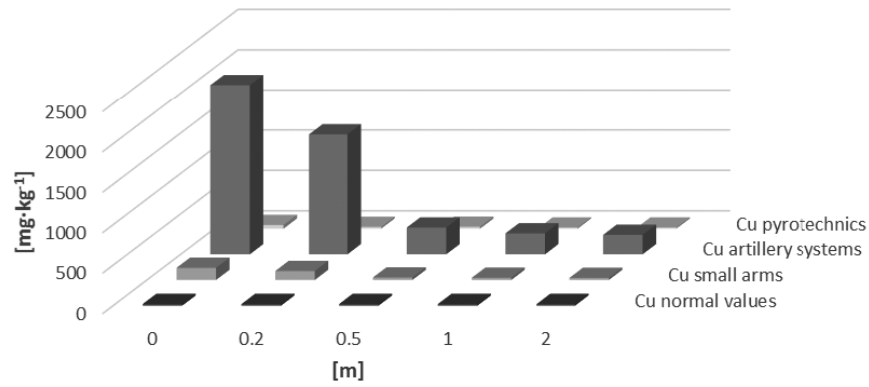

- Cu normal values $\quad$ Cu small arms $\quad$ Cu artillery systems $\quad$ Cu pyrotechnics

b)

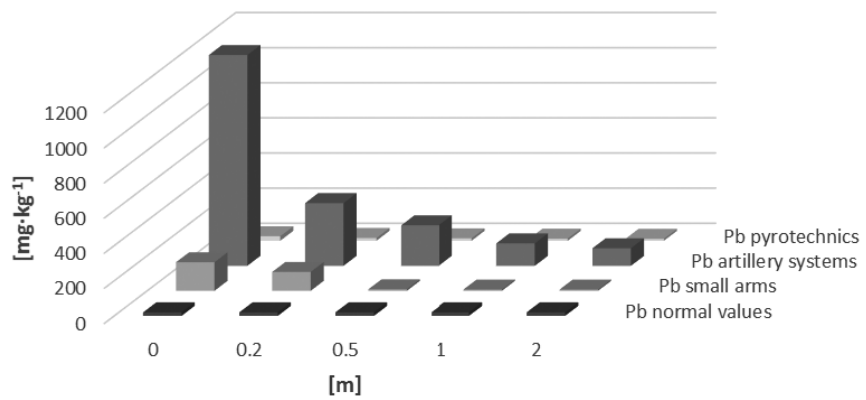

- $\mathrm{Pb}$ normal values $\quad \mathrm{Pb}$ small arms $\quad \mathrm{Pb}$ artillery systems $\quad$ Pb pyrotechnics

c) 


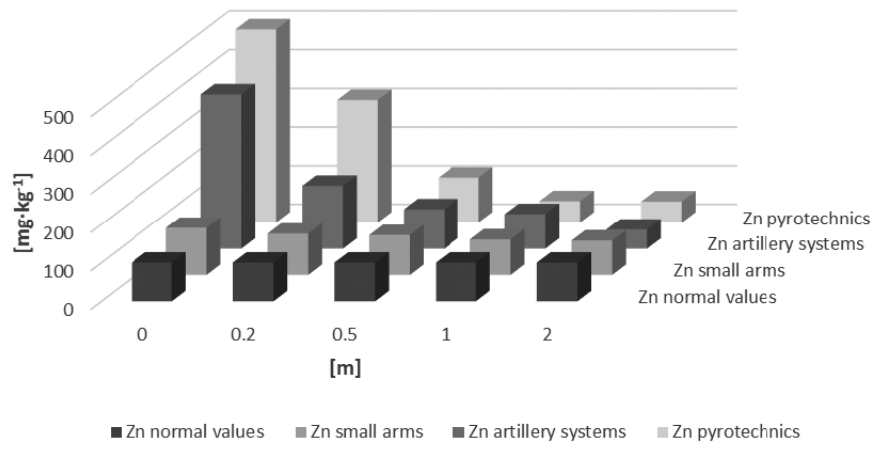

d)

Figure 4. Metal concentrations versus depth: a) $\mathrm{Hg}$, b) $\mathrm{Cu}, \mathrm{c}) \mathrm{Pb}, \mathrm{d}) \mathrm{Zn}$.

Furthermore, HPLC analysis of all soil samples gave no evidence of EM concentrations above the detection limit. The analyses for EM traces from the soil samples showed only the presence of nitro-aromatic derivatives from hot spot samples from the impact and disposal areas. Their concentrations were rather low, below $1 \mathrm{mg} \cdot \mathrm{kg}^{-1}$, and very close to the detection limit of the methods used $\left(0.3 \mathrm{mg} \cdot \mathrm{kg}^{-1}\right.$ for TNT and DNT). No sample analyzed showed the presence of nitramine-based compounds (RDX), which may be due to the reduced frequency of using munitions charged with these compounds and to their solubility. Deep soil samples (below $2 \mathrm{~m}$ ) showed no EMs.

\subsection{Vegetation sample evaluation}

The analysis results obtained from vegetation samples taken from the administrative area (BGL), the area of the small arms firing line, the pyrotechnics area and the UXO disposal site are illustrated in Table 2. At the present time, Romanian environmental legislation does not specify maximum thresholds for metals in vegetation, but this contamination should be monitored as a potential contributor to soil contamination, and the LBGL for soils was used for comparison. For specific hot spots, the metal concentrations were very high. Strongly contaminated spots were found with high $\mathrm{Cu}\left(1180 \mathrm{mg} \cdot \mathrm{kg}^{-1}\right), \mathrm{Pb}\left(671 \mathrm{mg} \cdot \mathrm{kg}^{-1}\right)$, and $\mathrm{Sb}\left(87.5 \mathrm{mg} \cdot \mathrm{kg}^{-1}\right)$ concentrations, in the area of the small arms firing line. Composite samples also showed high concentrations of $\mathrm{Cu}\left(321.75 \mathrm{mg} \cdot \mathrm{kg}^{-1}\right)$ and $\mathrm{Sb}\left(23.29 \mathrm{mg} \cdot \mathrm{kg}^{-1}\right)$, above the alert threshold levels for soils. In the areas where smoke munitions were burned, the grass was found to be extremely contaminated with $\mathrm{Zn}$ compounds $\left(10,140 \mathrm{mg} \cdot \mathrm{kg}^{-1}\right)$, due to the high levels of $\mathrm{Zn}$ in the aerosols released from the $\mathrm{HCH}$-based smoke generating devices. Composite samples 


\begin{tabular}{|c|c|c|c|c|c|c|c|c|c|c|c|c|c|c|c|c|c|}
\hline 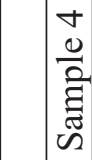 & $\frac{n}{\infty}$ & $\begin{array}{l}m \\
\\
0\end{array}$ & 1 & $\Xi$ & $\stackrel{\searrow}{\sim}$ & $\stackrel{\check{\sim}}{\check{\sim}}$ & $\because$ & $\stackrel{m}{\dot{\theta}}$ & I & 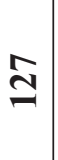 & $\begin{array}{l}0 \\
\stackrel{\sim}{0}\end{array}$ & $\tilde{n}$ & $m$ & 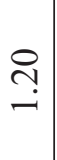 & 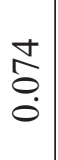 & $\begin{array}{l}\tilde{\alpha} \\
\stackrel{+}{0}\end{array}$ & ले \\
\hline 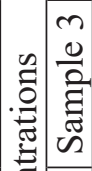 & $\stackrel{\overline{0}}{\dot{0}}$ & $\begin{array}{l}\hat{n} \\
0 \\
0\end{array}$ & 1 & 1 & $\stackrel{\nabla}{\sim}$ & $\stackrel{\curvearrowleft}{ \pm}$ & $\underset{-}{0}$ & $\frac{\mathfrak{T}}{\dot{\theta}}$ & I & $\mathfrak{N}$ & $\begin{array}{l}n \\
\tilde{n}\end{array}$ & $\bar{a}$ & $n$ & $\underset{\sim}{\stackrel{\odot}{+}}$ & I & $\frac{0}{n}$ & 1 \\
\hline 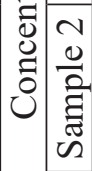 & $\tilde{n}$ & 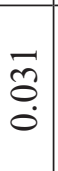 & 1 & I & $\stackrel{\mathrm{N}}{ }$ & $\stackrel{\infty}{ }$ & $\stackrel{n}{+}$ & $\frac{n}{\dot{\theta}}$ & I & $\stackrel{n}{\theta}$ & 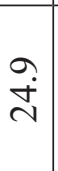 & $\stackrel{n}{ \pm}$ & $r$ & $\stackrel{n}{n}$ & I & $\begin{array}{l}0 \\
\infty \\
m \\
0\end{array}$ & $\stackrel{+}{\stackrel{+}{c}}$ \\
\hline 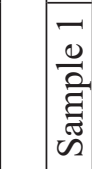 & $\begin{array}{l}\stackrel{ }{\sigma} \\
\stackrel{0}{0}\end{array}$ & $\frac{n}{n}$ & gิ & $a$ & $\hat{n}$ & $\stackrel{ }{\stackrel{ }{\sim}}$ & $\tilde{n}$ & $\underset{\theta}{0}$ & I & $\mathfrak{N}$ & $\begin{array}{l}0 \\
\dot{J}\end{array}$ & $\underset{b}{6}$ & $n$ & $\stackrel{\overbrace{}}{-}$ & $\stackrel{\mathscr{n}}{\stackrel{n}{+}}$ & $\begin{array}{l}n \\
n \\
n \\
0\end{array}$ & $\stackrel{\Re}{=}$ \\
\hline 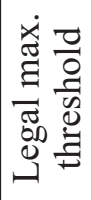 & 은 & $n$ & $\stackrel{8}{\circ}$ & $\stackrel{\circ}{n}$ & 요 & $\begin{array}{l}8 \\
8 \\
i\end{array}$ & $\stackrel{0}{-1}$ & $\overrightarrow{0}$ & $n$ & $\stackrel{\curvearrowright}{\sim}$ & 으 & § & ஓ & 1 & $\overrightarrow{0}$ & $\stackrel{\Upsilon}{\simeq}$ & 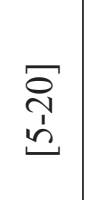 \\
\hline 句 & $\begin{array}{l}T \\
\dot{b}_{0} \\
\text { E्g }\end{array}$ & 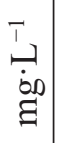 & 家 & $\begin{array}{l}T \\
\overrightarrow{\dot{b}_{0}} \\
\Xi\end{array}$ & 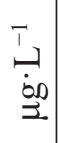 & $\begin{array}{l}T \\
\underset{0}{\dot{b}_{0}} \\
\end{array}$ & $\begin{array}{c}T \\
\vec{i} \\
\stackrel{5}{\Xi} 0 \\
\end{array}$ & 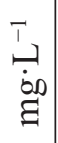 & 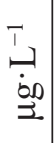 & 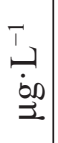 & 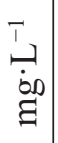 & 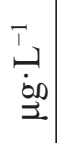 & $\begin{array}{l}T \\
\underset{5}{0} 0 \\
ت\end{array}$ & 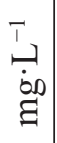 & 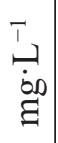 & $\begin{array}{l}T \\
\dot{D}_{0} \\
\Xi\end{array}$ & 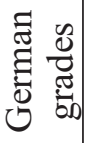 \\
\hline 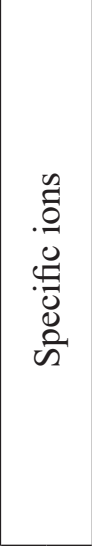 & 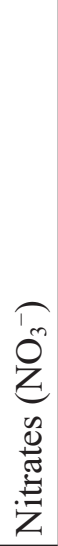 & 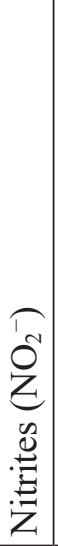 & 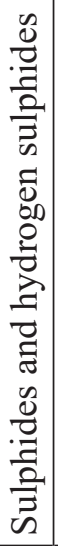 & 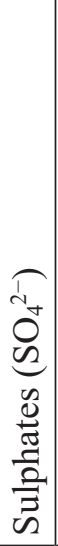 & 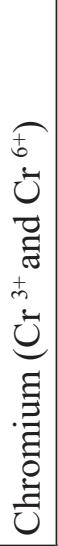 & 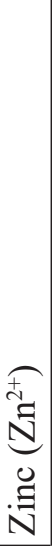 & 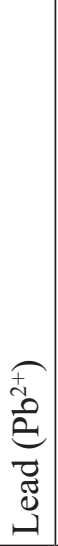 & 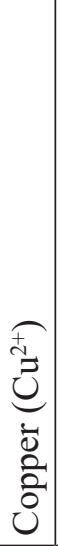 & 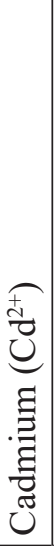 & 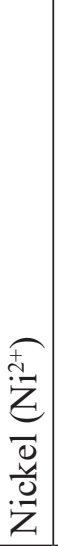 & 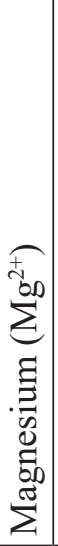 & 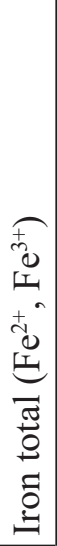 & 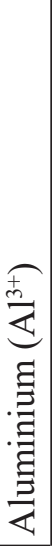 & 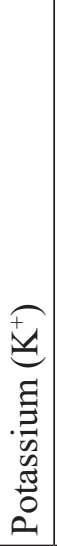 & 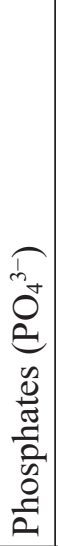 & 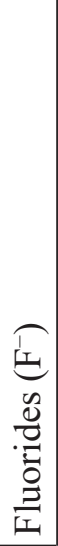 & 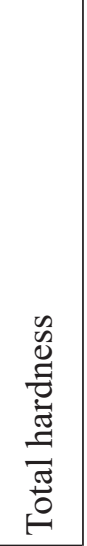 \\
\hline$\dot{0}$ & - & $\sim$ & $m$ & $\nabla$ & $n$ & 6 & $\lambda$ & $\infty$ & $a$ & $\stackrel{0}{1}$ & 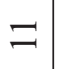 & $\simeq$ & $m$ & $\Xi$ & $n$ & $\underline{-}$ & I \\
\hline
\end{tabular}


collected in this area also showed high concentrations of $\mathrm{Zn}\left(439.56 \mathrm{mg} \cdot \mathrm{kg}^{-1}\right)$ versus BGL, but still below the alert threshold for soils.

\subsection{Anions, cations, heavy metals and EMs in the aquifer}

Table 3 presents the results obtained by analyzing four water tests taken in triplicate samples from the same well at three month-intervals, during one year. The same water samples were analyzed by AAS in order to confirm the metal concentrations determined by VIS spectrometry. The results are given in Table 4 and they are in agreement with the VIS spectrometric analysis, excluding those for $\mathrm{Cu}$ where slightly higher concentrations were recorded by AAS.

Table 4. Metal concentrations in water samples by AAS

\begin{tabular}{|c|c|c|c|c|c|}
\hline \multirow{2}{*}{ No. } & \multirow{2}{*}{ Sample } & \multicolumn{4}{|c|}{ Metal concentrations } \\
\cline { 3 - 6 } & $\begin{array}{c}\mathrm{Hg} \\
{\left[\mu \mathrm{g} \cdot \mathrm{L}^{-1}\right]}\end{array}$ & $\begin{array}{c}\mathrm{Pb} \\
{\left[\mu \mathrm{g} \cdot \mathrm{L}^{-1}\right]}\end{array}$ & $\begin{array}{c}\mathrm{Cu} \\
{\left[\mathrm{mg} \cdot \mathrm{L}^{-1}\right]}\end{array}$ & $\begin{array}{c}\mathrm{Zn} \\
{\left[\mu \mathrm{g} \cdot \mathrm{L}^{-1}\right]}\end{array}$ \\
\hline 1 & Sample 1 & $\mathrm{udl.} *$ & 3.2 & 0.16 & 354 \\
\hline 2 & Sample 2 & udl.* $^{*}$ & 6.5 & 0.25 & 230 \\
\hline 3 & Sample 3 & udl.* $^{*}$ & 1.5 & 0.25 & 195 \\
\hline 4 & Sample 4 & udl.* & 2.0 & 0.23 & 315 \\
\hline
\end{tabular}

*udl. = under the detection limit of the method (detection limit for $\mathrm{Hg}$ concentration was $\left.0.002 \mu \mathrm{g} \cdot \mathrm{L}^{-1}\right)$.

According to the Romanian national regulations regarding the quality of water, the maximum threshold for $\mathrm{Hg}$ concentration is $1 \mu \mathrm{g} \cdot \mathrm{L}^{-1}$.

As may be observed, only a slight contamination of the aquifer with $\mathrm{Ni}$ and $\mathrm{Cu}$ was identified, while all of the other parameters were shown to be within the normal limits. However, taking into account the heavy metal concentration distributions in the deep soil, the $\mathrm{Cu}$ and $\mathrm{Ni}$ high concentrations cannot be accounted for the military activity at the range.

Furthermore, tests using the REX KIT 08 have shown no traces of EM nitro-derivatives in the water samples.

\section{Conclusions}

It is not only the utilization of munitions which is a major factor affecting the environment and human health, but the entire life cycle of the munitions. Therefore, production, demilitarization and destruction are stages that all contribute to the release of toxic compounds into the environment. A complete 
characterization of explosives production, demilitarization and disposal facilities, instruction and firing ranges all make contributions to an environmental impact evaluation in order to give essential information on the requirements, remediation measures and the procedures necessary for the minimization of hazardous effects against the environment.

In order to develop and test the instrumental methods for the long term impact evaluation of munitions on the experimental range, specific procedures for sampling, for testing and analysis were set, and results interpretation criteria were identified. Valuable data on EM and heavy metal pollution were obtained for the soil, water and vegetation on the range.

The study was performed at an important testing range of the Romanian MoD, searching for evidence of soil, ground water and vegetation contamination with heavy metals and EMs resulting from firing of infantry and artillery munitions. The tests performed confirmed the presence of EMs and heavy metals as contaminants, with a heterogeneous distribution on the range. The contamination was concentrated in the areas of the firing line for small caliber and large caliber armament systems, where combustion products and residues, as well as metallic fragments, are dispersed during the firing of conventional munitions. The main contaminants found were $\mathrm{Hg}, \mathrm{Pb}, \mathrm{Cu}, \mathrm{Sb}$ and $\mathrm{Zn}$, which are constituents of EMs or come from the erosion of exposed surfaces of the ammunition. Analysis of deep core samples demonstrated that the contamination with heavy metals is limited to the upper layer $(<0.5 \mathrm{~m})$ of soil, so that transport of the contaminants to the aquifer is very unlikely. A slight contamination of the aquifer with $\mathrm{Ni}$ and $\mathrm{Cu}$ was detected, but the values obtained cannot be attributed solely to military activities.

Only a slight contamination of the surface soil with heavy metals and EMs, specifically nitro-aromatic compounds, was found in the impact area and in the area of UXO neutralization, but mostly around the craters. The depth analysis gave no evidence for the presence of such compounds below $2 \mathrm{~m}$.

Vegetation samples were also analyzed and found to be qualitatively in line with the soil contamination, but showing higher concentrations of the contaminants. This indicates that deposition of products and residues on the vegetation is the first step in soil contamination.

From the analyses performed on the Romanian experimental range, one may conclude that the environment hazard of classic infantry and artillery armament systems is significant, by spreading EMs and metals through: deposition of incomplete burning products and of metallic debris on the ground and vegetation; dispersion of projectiles, cartridge tubes, fuses, etc. and other parts, resulting from firing; dispersion into the soil of UXOs or partially exploded items during firing or neutralization. 
A rigorous record of the munitions fired, combined with data on the specificity of the compounds released into the environment and permanent monitoring of the extent of contamination of the exposed areas, would contribute to an accurate risk assessment and to correct decisions regarding the corrective measures to be undertaken.

\section{Acknowledgements}

The authors thank the Scientific Research Center for CBRN Defense and Ecology and Military Technical Academy for the tests and analyses funding, and the Jegalia Range staff for their professional help in achieving the data for the present study.

\section{References}

[1] Characterization and Remediation of Soils at Closed Small Arms Firing Ranges. SMART-1. Washington, D.C.: Interstate Technology \& Regulatory Council (ITRC), Small Arms Firing Range Team, 2003; Available at http://www.itrcweb.org.

[2] Environmental Management at Operating Outdoor Small Arms Firing Ranges. SMART-2. Washington, D.C.: Interstate Technology \& Regulatory Council (ITRC), Small Arms Firing Range Team, 2005; Available at http://www.itrcweb.org.

[3] Warren S.D., Holbrook S.W., Dale D.A., Whelan N.L., Elyn M., Grimm W., Jentsch A., Biodiversity and the Heterogeneous Disturbance Regime on Military Training Lands, Restor. Ecol., 2007, 15(4), 606-612.

[4] Andersen M.C., Thompson B., Boykin K., Spatial Risk Assessment Across Large Landscapes with Varied Land Use: Lessons from a Conservation Assessment of Military Lands, Risk Anal., 2004, 24(5), 1231-1242.

[5] Dermatas D., Chrysochoou M., Grubb D.G., Xu X., Phosphate Treatment of Firing Range Soils: Lead Fixation or Phosphorus Release?, J. Environ. Qual., 2008, 37, 47-56.

[6] Padmavathiamma P.K., Li L.Y., Phytoremediation Technology: Hyper-accumulation Metals in Plants, Water Air Soil Pollut., 2007, 184, 105-126.

[7] Greenberg M., Burger J., Gochfeld M., Kosson D., Lowrie K., Mayer H., Powers C.W., Volz C.D., Vyas V., End-state Land Uses, Sustainably Protective Systems, and Risk Management: a Challenge for Remediation and Multigenerational Stewardship, Remediation, 2005, 91-105.

[8] Martel R., Mailloux M., Gabriel U., Lefebvre R., Thiboutot S., Ampleman G., Behavior of Energetic Materials in Ground Water at an Anti-Tank Range, J. Environ. Qual., 2009, 38, 75-92.

[9] Walsh M.R., Walsh M.E., Ampleman G., Thiboutot S., Brochu S., Jenkins T.F., Munitions Propellants Residue Deposition Rates on Military Training Ranges, 
Propellants Explos. Pyrotech., 2012, 37(4), 393-406.

[10] STANAG 4359 EN-NATO, Handbook for Sampling and Identification of Chemical Warfare Agents - AEP-10-ED 1 AMD 1 Amendment 1: 2/28/96.

[11] SR ISO 11047:1999, Soil Quality. Assessment of Metals by AAS.

[12] SR ISO 8288:2001, Water Quality. Assessment of Metals by AAS.

[13] Walsh M.R., Walsh M.E., Hewitt A.D., Energetic Residues from Field Disposal of Gun Propellants, J. Hazard. Mater., 2010, 173, 115-122.

[14] Bobes-Tureac A.C., Grigoriu N., Petre R., Rotariu T., Low Detection Limits of Nitro Organic Explosives from Soil by High-Performance Liquid Chromatography using Photo Diode Array Detector, The $19^{\text {th }}$ Int. Conf. the Knowledge Based Organization, Sibiu, Romania, 2013, 198-203.

[15] Bennett J.R., Kaufman C.A., Koch I., Sova J., Reimer K.J., Ecological Risk Assessment of Lead Contamination at Rifle and Pistol Ranges Using Techniques to Account for Site Characteristics, Sci. Total Environ., 2007, 374, 91-101.

[16] Hardison Jr. D.W., Ma L.Q., Luongo T., Harris W.G., Lead Contamination in Shooting Range Soils from Abrasion of Lead Bullets and Subsequent Weathering, Sci. Total Environ., 2004, 328, 175-183.

[17] Sanderson P., Naidu R., Bolan N., Ecotoxicity of Chemically Stabilised Metal(loid)s in Shooting Range Soils, Ecotox. Environ. Safe., 2014, 100, 201-208. 
